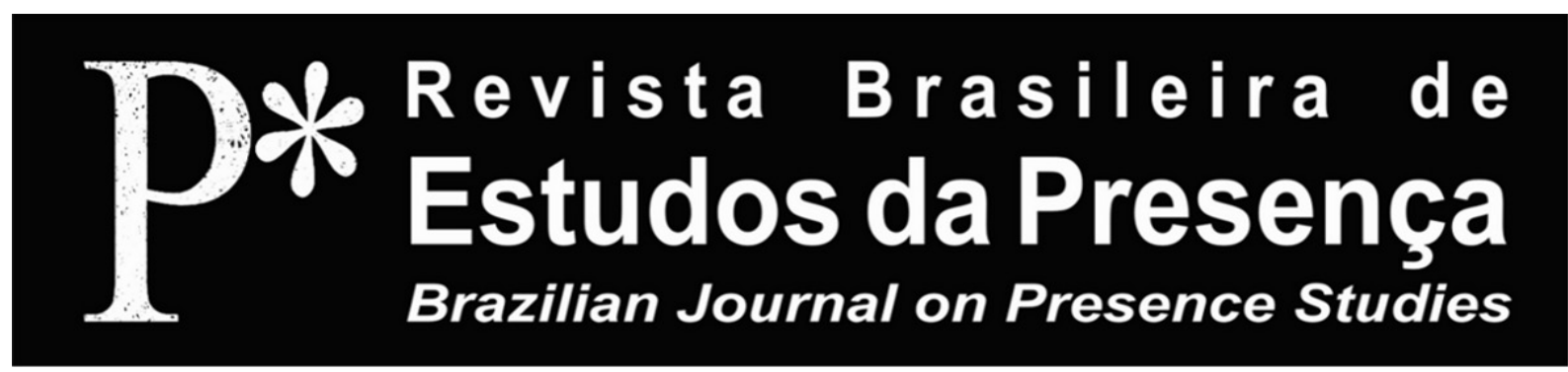

DOI - http://dx.doi.org/10.1590/2237-266046364

ISSN 2237-2660

\title{
Pesquisa em Performance: encontro, palavra e corpo
}

Aldo Victorio Filho Filipe Espindola

Rodrigo Guéron Sara Panamby

Universidade do Estado do Rio de Janeiro - UERJ, Rio de Janeiro/RJ, Brasil

RESUMO - Pesquisa em Performance: encontro, palavra e corpo - Este é um artigoencontro, um artigo-diálogo entre dois professores-pesquisadores e dois artistas dedicados à performance e que também têm a universidade como espaço de experimentaçáo: Sara Panamby e Filipe Espindola. Neste encontro, tentamos traduzir em palavras os afetosensinamentos das experiências limites do casal. A pergunta sobre o que é a performance, e especificamente as experiências criadas pelos performers conduziram-nos a exemplos das dores e amarras que condicionam nossos corpos, violências biopolíticas em algumas das suas dimensóes, mas também às forças, às dores de libertação e às delícias que podemos produzir para escapar à jaula afetiva e sensório-motora que nos coloniza. Descolonizaçáo dos corpos de toda a violência, mas também intercolonizaçáo que fez de todos nós outros ali: aprendizado que só pôde acontecer por uma certa violência, espanto e maravilhamento. Palavras-chave: Performance. Palavra. Corpo. Sara Panamby. Filipe Espindola.

ABSTRACT - Research on Performance: meeting, word and body - This is a meetingarticle, a dialogue-article between two teachers-searchers and two artists dedicated to the performance and who also have the university as a space of experimentation: Sara Panamby and Filipe Espindola. In this meeting we tried to translate in words the teaching/affections of the couple's experiences. The question about what the performance is, and specifically the experiences created by the performers, led us to examples of the pains and moorings which condition our bodies, bio-political violences in some of their dimensions, but also to the strengths, to the pains of freedom and to the delights that we can produce to escape from the affective and sensory-motor cage that colonizes us. Decolonization of the bodies from all the violence, but also cross-colonization that makes all of us others there: a learning that could only happen because of a certain violence, astonishment, and amazement.

Keywords: Performance. Word. Body. Sara Panamby. Filipe Espindola.

RÉSUMÉ - Recherche sur la Performance: rencontre, parole et corps - Il s'agit d'un article-rencontre, un article-dialogue entre deux professeurs/chercheurs et deux artistes dédiés à la performance et qui ont aussi l'université comme un lieu d'expérimentation: Sara Panamby et Filipe Espindola. Lors de cette rencontre, nous avons essayé de mettre en mots les affects-apprentissages des expériences limites du couple. La question sur ce qu'est la performance, et en particulier les expériences qu'ils ont créées, nous ont conduits à des exemples des maux et des chaînes qui conditionnent nos corps, les violences biopolitiques dans certaines de ses dimensions, mais, aussi aux forces, aux douleurs de libération et aux plaisirs que nous pouvons produire pour échapper à la cage affective et sensorimotrice qui nous colonise. La décolonisation des corps de toutes les violences, mais aussi l'intercolonisation qui nous a fait devenir les autres là: un apprentissage qui ne peut arriver que par une certaine violence, étonnement et émerveillement.

Mots-clés: Performance. Parole. Corps. Sara Panamby. Filipe Espindola. 

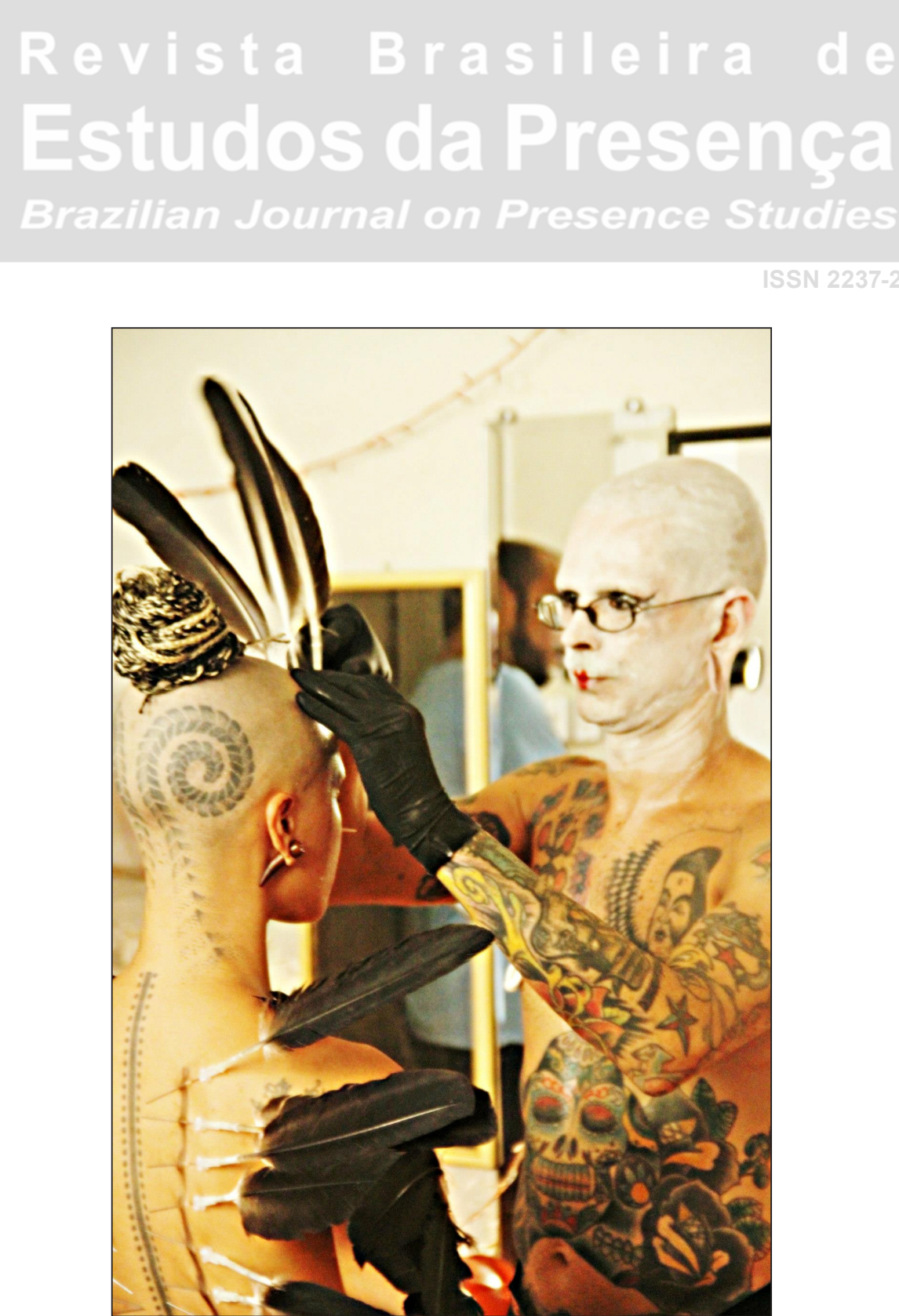

Imagem 1 - Sara Panamby e Filipe Espindola durante a performance A Sagração de Urubutsim. Foto: Zulu Aborigeni.

Este trabalho resulta de um encontro dionisíaco entre dois professores-pesquisadores do Programa de Pós-graduação em Arte da Universidade do Estado do Rio de Janeiro, Aldo Victorio e Rodrigo Guéron, e dois artistas dedicados à performance, Filipe Espindola e Sara Panamby. Esses dois artistas não produzem apenas obras de arte, são pesquisadores para além das necessidades intrínsecas aos seus atos poéticos. Dedicam-se com franca energia ao pensamento desfronteirado do que fazem. Sara é mestre e doutoranda do mesmo programa, e Filipe é bacharel em Artes Plásticas; juntos, ofereceram seu ateliê para o encontro/entrevista, cujo objetivo inicial era a coleta de material para a produção de um artigo para esta revista. Contudo, diante da potência das colocaçôes e da força coletiva da conversa, optamos por publicar a transcrição, quase integral, do diálogo. Entendemos que a discussáo que se daria sobre a performance resultou 


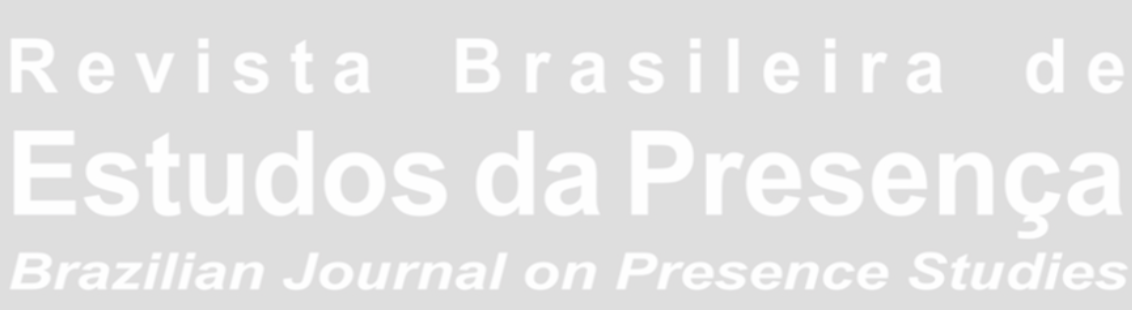

ISSN 2237-2660

em uma obra performática que, assentada na fricção palavra/corpo, supera polarizaçóes e alcança, no nosso entendimento, a performatividade da palavra.

Essa mesma casa-ateliê, onde, de certa forma, o estar em casa é performado num ninho-ritornello - um em-casa para onde os artistas voltam para o descanso e entram num repouso de re-significâncias, de imersóes semióticas, de gozos, sonho e sonos - foi, há não muito tempo, o espaço da performance poética que constituiu a defesa da dissertação de mestrado de Sara, defesa esta realizada numa banca montada ali mesmo no quintal logo em seguida ao ato: a performance A Sagração de Urubutsin.

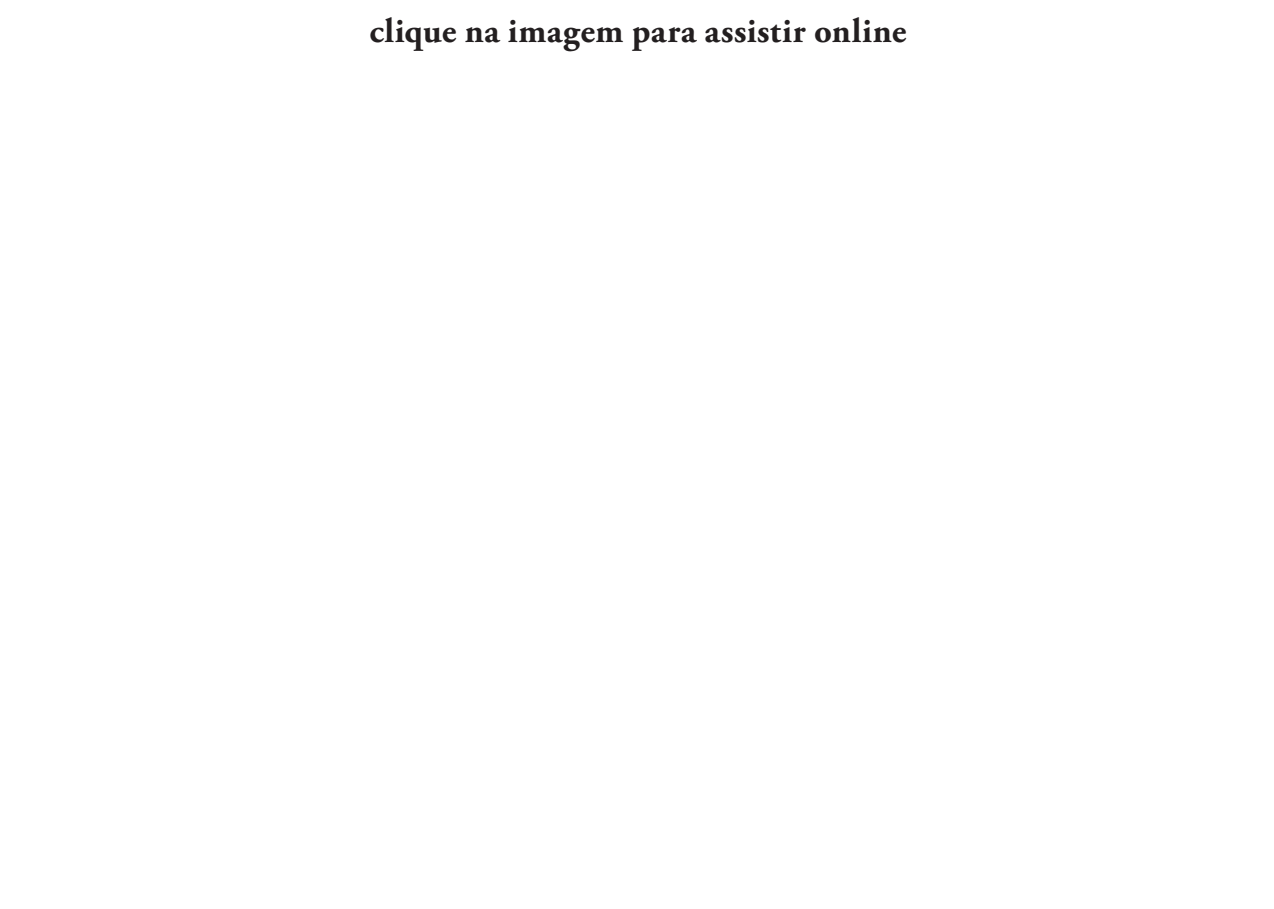

Vídeo 1 - Minutos finais da performance A Sagração de Urubutsin, de Sara Panamby e Filipe Espindola, durante a defesa da dissertação de mestrado de Sara (PPGARTES/UERJ), realizada na sua casa em Santa Tereza, no Rio de Janeiro. Imagens: Alex Barbosa, Rodrigo Guéron e Kezia Jacomo.

Da mesma forma, como foi dito no nosso encontro, a saber, que o aluno deve colonizar o professor, Sara e Filipe nos colonizaram. Um foi colonizado, na medida em que se tornou o orientador (Aldo Victorio), e o outro (Rodrigo Guéron), quando estava em meio ao concreto frio da UERJ, sujeitado às imposições burocráticas kafkanianas da instituição e foi chamado às pressas para ir à sala onde Sara e Filipe performavam como parte da qualificação do mestrado. Esse encontro nos arrancou do lugar miserável que a universidade muitas vezes insiste em nos deixar, mas, justiça seja feita, foi um encontro 
na universidade. No entanto, tudo, por um instante, ainda naquela tarde de qualificação, ficou fora do lugar. Provisoriamente salvos de sermos baratas kafkanianas do produtivismo, a potência da performance se deu ali porque ali não era o lugar daquilo. E assim fez-se outro lugar. Sala de aula não era mais sala de aula, índio não era índio, pássaro não era pássaro, artista não era mais artista, alunos não eram mais alunos, professores não eram mais professores, e a própria performance só pôde ser chamada como tal porque estava fora do espaço que a consagrou, como um modo institucionalizado de expressão artística. Mesmo depois, na casa de Sara, produziu-se um imenso fora de casa, um fora do lugar esperado de uma defesa de dissertação, e o acolhimento delicioso daquela casa-ninho esquentou os coraçóes e fez requebrar os corpos às vezes táo gelados e duros das defesas acadêmicas. Tivemos, então, a festa!

Nessa colonização de nós, professores, cada um reencontrou e repotencializou suas pesquisas. Uma em torno das interseçóes entre a Educação, a Arte e das estéticas periferizadas como fontes epistêmicas vitais à formação humana contemporânea. A outra, sobre as relaçóes entre Arte e Política, neste caso materializadas na imagem - e a imagem, de certa forma, é sempre matéria - que é política na medida em que se faz imagem impossível: a imagem cheia de sensorialidade limite construída por Sara e Filipe. Só para começar, Sara e Filipe em performance-signo nos fizeram experimentar que a imagem é matéria viva, que o nomos é este em-casa onde o corpo vira, ao mesmo tempo, dínamo e trandutor das energias do Caosmos e, em suas confluências, permite-se ao pré-humano ato criador.

No pássaro índio de Sara, as penas náo são ornamentos, podem ser registros no corpo, inscriçóes - mas, se fosse só isso, soaria como uma pena desde fora e sobre o corpo. O pássaro índio de Sara é a conquista da beleza pela maculação, a criação como a negação de qualquer virgindade e pureza, a força no corpo e na vida que é quase violenta (ou violenta de fato) e alcança o esplendor.

Entáo, nessa entrevista, na qual se lembrou a grande festa daquele dia, pusemo-nos a falar em meio a um Rio de Janeiro cheio de uma rebeldia imprevisível, excitantemente perigosa e libertária. Estávamos felizes com tudo isso, mas alertas com as violências do Estado e da Capital que afloram e contra as quais nos eriçamos como um bicho pronto para a briga e/ou para o acasalamento. Pensamos, criamos, 
gaguejamos, comungamos, bebemos, comemos e politicamos. Um pouco desse meio que se cria nos encontros com Sara e Filipe está aí embaixo, e esperamos que continue estando para muito além destas páginas e para além do blá-blá-blá (nhém-nhém-nhém, diriam os Tupinambás) de nossas tantas vezes débeis palavras.

Aldo Victorio: Verdade e mentira: seria possível pensar no ato performático, de alguma maneira, na perspectiva dessa polarização? Ou o acontecimento da performance implicaria na superaçáo integral dessas polaridades?

Sara Panamby: Performance é um negócio muito louco, que eu não sei mais se faz parte do campo da arte. Eu náo sei mais de que campo é a performance, nem se a performance é alguma coisa. Eu acho que é o acontecimento, momento da presentificação, que é como um despacho. Quando você faz um despacho, você vai lá e pronto. Pronto, acabou. Você faz aquele instante de beleza para ele apodrecer. Então acho que a performance é isso que acontece na rua, quando o cara está carregando um carrinho cheio de sacos e fica uma puta instalação. Você olha e percebe para além da visualidade. Perplexidade: um momento de suspensão mesmo da realidade.

AV: Realidade narrável?

SP: Narrável e sempre ficcionalizável.

AV: Representável pela palavra? Haveria ainda uma força superior da palavra no campo de acontecimento do gesto?

SP: Eu acho. Entretanto, mesmo quando tem a palavra, a palavra já não é mais palavra. É bem a ação do ator, no sentido de que a palavra visceraliza a ação. A palavra que é ação e gesto também.

AV: Sara, quando você despotencializa a palavra no ato performático, questão crucial para pensar a performance, então, o que resta quando a gente tira a palavra?

SP: Quando a gente tira a palavra, resta todo o resto (risos). E resta aquilo que faz parte do mais sensual, do mais sensível.

AV: Resta o corpo?

SP: É. Eu acho que o corpo sempre vai para além da palavra. Por mais que a palavra esteja escrita, ou que ela seja transcrita, ou que ela seja escrita pelo corpo. Ela sempre vai ser aquém e além do corpo, mas ela nunca vai chegar a ser corpo. Melhorando um pouco, 
para a gente fazer corpo com a palavra, ela precisa ser muito louca: a palavra que fica frenética.

AV: Poesia?

SP: Poesia. Poesia, radicalmente poesia.

AV: Mas vamos dizer que ela chegasse a essa constelaçáo do corpo. A palavra, então, pode ser carnificada. Carnificada quando, de fato, há uma incorporação.

SP: Sim.

AV: Sara, vemos hoje uma atenuação de um problema limite: a negação do corpo na construção da vida pelo discurso, da vida teorizada na qual o corpo está ausente. O corpo está sempre ultrapreservado, subjugado a determinados princípios estéticos instrumentais do capitalismo e, na contramão, a contrapelo desse processo mercadológico de isenção do corpo e de sua ultraproteção, é justamente no ato poético da performance que a gente vê um corpo exposto a todas as intempéries estéticas e poéticas, um corpo projetado até a dor. Gostaria que você me falasse um pouco isso.

SP: Tem algo que eu li uma vez na faculdade e que eu não lembro se era do Heidegger ${ }^{1}$, que eu achava lindo. Era o lance de que, quando você se joga no abismo, você cai para o alto, porque, quando você muda seu centro gravitacional, tudo muda. E acho que isso pode ser visto tanto no sentido físico das coisas quanto na física dos corpos vibráteis. Pensando na performance do corpo... Você tem um eixo que te puxa para cima pela pele, que é uma medida que talvez você só tenha quando nasce, e uma outra medida que te puxa para baixo. De repente, teu corpo tem dez metros. E tem ainda o outro sentido da gravidade das coisas, o sentido metafórico de mudar a gravidade, de mudar o registro de percepção da agudeza das coisas, alterar a musicalidade das coisas.

AV: Falemos do redimensionamento desse corpo na sociedade colonizada, num sistema de coisas em que quase há a obrigatoriedade do corpo ocupar cada vez mais o espaço restrito à uma representaçáo de interesse econômico: um corpo saudável, um corpo bombado, higienizado e tal. Contudo, mesmo nessa lógica, nessa estética, o corpo transgride, o exemplo quase freak, pelo menos em determinado momento de suas intervençóes corporais, da nossa querida Valesca Popozuda ${ }^{2}$. 
SP: Que arrasa! Que é luxo... Ela transgride, transgride horrores. Acho que é interessante a gente falar, talvez nem só em performance exatamente, porque já tá um negócio meio instituído... A gente tem os editais para performance, tem os festivais de performance, as mostras, as exposiçóes, o caralho todo, e a gente deixa de pensar na performatividade das coisas fora da institucionalidade da linguagem artística. Veja no que o pessoal da teoria pensa... Você imprime a linguagem, a açáo, o fazer, o acionamento. E tanto que a palavra pode ter também esse grau de crueldade que o Artaud fala e que o corpo tem já quando ele se torna ou pode se tornar muito cruel, a palavra imposta. Bem, o que a gente tá vendo agora mesmo, a palavra imposta pelo governo, que fala que gastará sessenta mil para fazer não sei o quê, plantar uns coqueiros imperiais lá na frente do Maracanã, mas não tem dez mil para pagar um equipamento que tá faltando em um hospital. Então, assim, a palavra aí já tem um poder corpo que é evidente, é claro, ele define a vida e a morte. E aí acho que é interessante a gente pensar a performatividade, que pode estar tanto no corpo do performer, que tá pensando a linguagem, que está pensando uma plasticidade, uma dramaturgia das coisas, quanto no corpo do morador de rua, quanto no corpo do cara que fica muito bêbado todo dia no mesmo bar, quanto no corpo do funkeiro e no da Valesca.

AV: Você se refere à preocupação formal, técnica, como uma possível sintaxe do corpo?

SP: É.

AV: Outra questão que me ocorre: o desejo. Ele é falado, é afirmado a partir da palavra e na voz. Haveria um desejo, uma possibilidade de desejo do corpo que se projeta, que determina, que afirma uma interferência para além do jogo da palavra pensada, da palavra colonizadora do corpo?

SP: O corpo pode, mas o que o corpo pode? O que a gente pode tangenciar com o corpo, né? A experiência com modificação corporal, ela sempre me revela muito essa via de que o corpo consegue fazer aquilo também e mais para além de uma razão anterior definidora de supostos limites. O corpo pode mesmo fazer um monte de coisa louca, para além do entendimento da palavra. O desejo do corpo, acho que mora aqui mesmo, no corpo...

Rodrigo Guéron: Mas o desejo é no corpo? 
SP: O desejo não tem como não ser do corpo também.

RG: Não ser do corpo também, porque também não é igual ao desejo do corpo.

SP: Não sempre. Por exemplo, a gente tem o desejo de consumir, porque a gente viu a propaganda tal, e quando eu vejo a propaganda da Coca-Cola, me dá muita vontade de tomar uma Coca-Cola... A imagem aliada à palavra pode ter um poder imenso sobre o corpo e também por outras vias, que também são corpo, que também pensam, construídas pelo corpo.

AV: Separar mente do corpo ainda é um problema...

SP: É sempre um problema.

AV: Será que algum dia as palavras do Felipe a respeito da modificação da orelha dele vão alcançar aquilo que o corpo dele quis? $\mathrm{O}$ que a orelha dele quis? Náo consigo evitar a esquizofrenia aparente da questão, mas, para uma questão esquizo...

SP: Mas acho que é uma conversa a nível celular mesmo (risos).

AV: Será que ele daria conta do desejo de uma orelha que não fala com palavras? Que fala com desejo de perfuração e alargamento? É essa a minha questão.

SP: Ah, isso é muito bom, isso que é foda, porque é um negócio difícil de falar, porque a palavra não chega.

Felipe Espindola: $\mathrm{O}$ desejo é maior que as palavras.

AV: O que te leva ao sexo, por exemplo. Será que existe a possibilidade de a palavra dar conta plena do erótico?

FE: Tipo a pessoa que quer ter bulimia... Para ela, é importante. Ou que precisa comer até vomitar ou comer mais. Podemos pensar que a obesidade, algumas vezes, só seria mórbida para os outros...

SP: A modificação corporal compulsiva, o sexo compulsivo...

FE: A ausência de plantas e formas vivas dentro do apartamento. Sei lá, a pessoa quer estar sozinha, e a solidão é ótima para ela, por mais que ninguém nunca compreenda. Ela nunca vai conseguir explicar com palavras. O desejo supera a linguagem.

AV: E a performance leva a pensar essas coisas, um mundo onde a palavra foi abolida do seu sentido hegemônico.

SP: É a palavra periférica mesmo, a palavra que tá ali, para a gente moldar e brincar e delirar mesmo na palavra. Porque senão que graça tem a gente ficar blá-blá-blá e citar um nome de um autor a cada dez 
palavras?! Que é igual à merda... E a merda é uma obra muito mais complexa e simbólica (risos). A merda em si já é uma obra.

RG: Eu preciso entender que existe um caráter da palavra e um mundo da palavra que, num certo sentido, não é o logocentrismo etnocêntrico ocidental, porque o logocentrismo ocidental afirma o primado da palavra, que é uma operação de poder escancarada, na verdade, e que coloca as figuras do saber no lugar do sacerdote, sobretudo quando inventada a escrita. É ele quem interpreta a palavra ou que sabe o real significado da palavra... Ao mesmo tempo, a palavra como operação de poder emana potência, mas gera impotência, posto que a palavra serve como um instrumento de opressão. A palavra intimida. É preciso, entâo, ver a intimidação da palavra como parte da potência dela, e não apenas como uma coisa que o poder joga na nossa cabeça quase como um cassetete ou uma bala.

SP: Se trata de um comportamento viral, né? A gente tem a palavra como uma hegemonia. Para índio, a porra da palavra nunca teria essa importância, né? Porque tinha a cerâmica, tinha a pintura corporal Tem os rituais, a modificação, tudo que, em suas conexôes, dá conta do que a palavra se ocupa em nosso mundo quase sozinha.

RG: De onde vem o nhém-nhém-nhém, né? Que é o blá-blá-blá do homem branco, né?

SP: Exatamente.

RG: Os caras perceberam o falatório muito antes do Heidegger! Esses merdas desses brancos náo param de falar, o que é isso? $\mathrm{O}$ índio fica perplexo diante dessa verborragia.

SP: Um blá-blasé... É difícil mesmo...

RG: E, ali no meio, há uma extraordinariedade da palavra, há uma palavra rara... Ou a que produz um tipo de afeto, que dá um caráter corpóreo a ela, que faz dela um corpo vivo. Porque, nesse ponto, até as palavras parecem com os corpos, porque a maioria dos corpos também são mais ou menos mumificados, por vezes efetivamente menos potentes que as palavras...

AV: Estabilizados?

SP: Estabilizados também, entretanto, se qualquer pessoa, qualquer ser humano fica pelado, ele já é uma coisa muito interessante. A nudez desestabiliza.

RG: No sentido potente. Desestabilização que empodera. 


\section{Revista Brasileira de \\ Estudos da presenca \\ Brazillian Journal on Presence Studies}

AV: Os índios...

SP: Não é índio bonitinho!

RG: Índio virgem é insuportável!

AV: A ideia construída de índio puro...

RG: Isso está aí...

AV: Eu me lembro de quando descobriram os ianomâmis, interessantíssimos! Mas, veja, o que fizeram com eles é inacreditável!

RG: Diziam que eles eram mais puros que os outros. $\mathrm{Na}$ lógica eurocêntrica, mais primitivos.

AV: Eles não permitiam aproximaçáo. Mas, infelizmente vencidos, foram quase dizimados. Como dizia Darcy Ribeiro, "[...] é muito difícil para a nossa cultura suportar tanta beleza ${ }^{3 "}$.

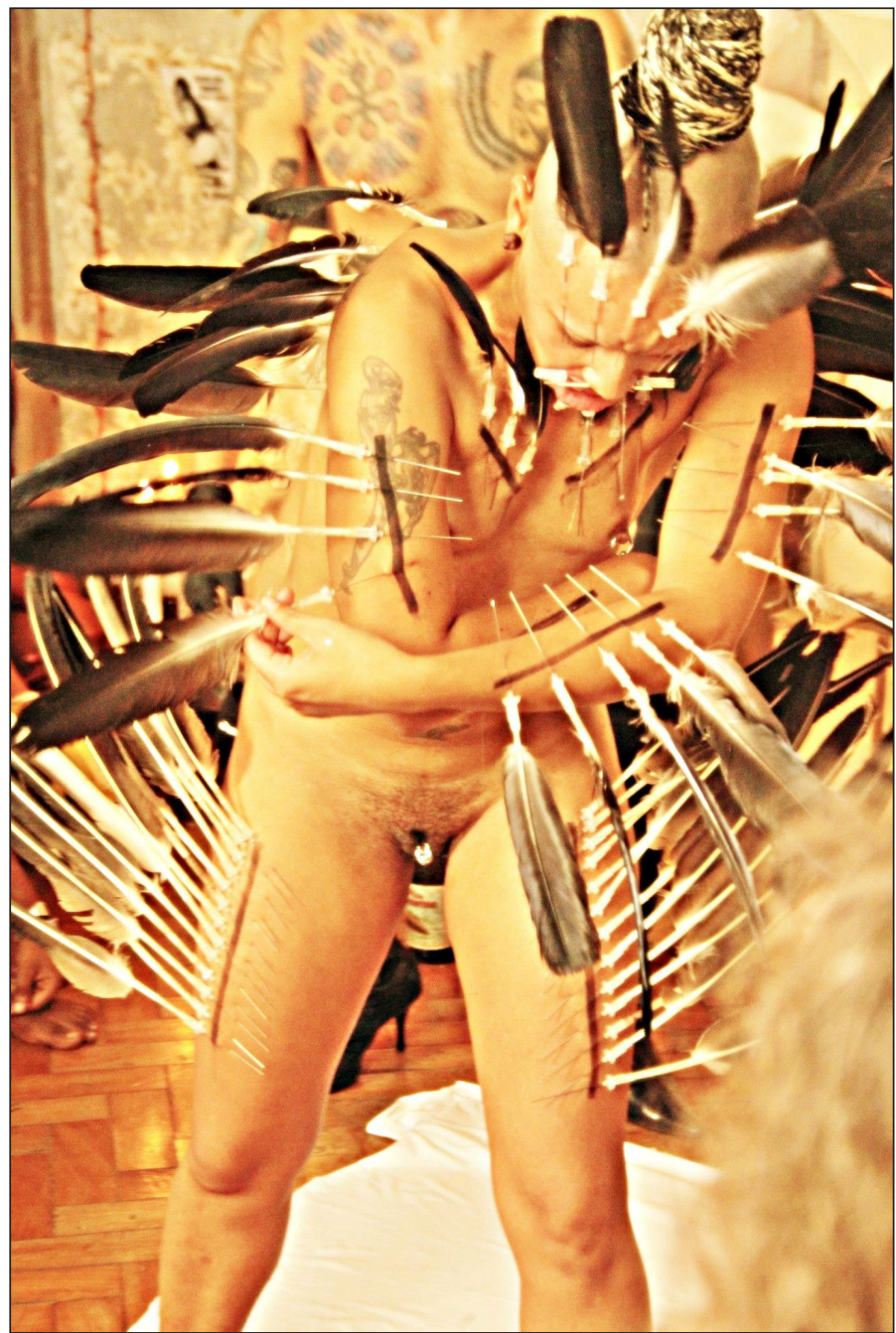

Imagem 2 - Sara Panamby durante a performance $A$ Sagração de Urubutsim. Foto: Zulu Aborigeni. 
FE: Aldo (lembrando o que você falou da minha orelha...), é, era uma orelha que queria ser índia. Em todos os carnavais, o meu personagem era o índio, pois era a possibilidade de pintar o corpo e sair com ele quase nu e de usar saia. Então eu reunia todos os desejos num momento só, pois eu ficava (quatro dias) pintado, seminu, nu, ou de saia, descalço. E aquilo dava até prêmio no saláo de melhor fantasia. E a palavra fantasia, neste caso, ainda é perfeita: a minha fantasia era ser índio!

RG: Retomando a pergunta para Sara, entáo, há uma primeira coisa ali, que é o ferimento com a flecha (se é que é assim que se pode dizer, mas foi essa palavra que me ocorreu). A flecha é fincada no corpo? Não é isso?

SP: Sim.

RG: Então a primeira coisa de sua performance seria o seguinte: aquilo não é ornamento! E isso é uma coisa interessante, porque discute com muitas coisas importantes, várias operaçóes de captura e até com coisas que tiveram a sua potência em algum momento, desde o índio de carnaval que desfila na escola de samba até o índio de uma certa antropologia romântica, náo sendo injusto com outra antropologia que busca o pensamento potente a partir dali, mas falo de uma antropologia, por exemplo, que disse que náo iria se posicionar perante a luta da Aldeia Maracanã ${ }^{4}$, porque aqueles índios não eram mais índios puros!

SP: Então vai tomar no cu.

RG: Exatamente!

RG: E aí tem uma visão de natureza... Até vou evocar a fala do Žižek ${ }^{5}$, embora ele tenha dito e escrito muitas coisas com que eu não concordo absolutamente, mas ele cria uma tensão muito interessante quando fala que o Evo Morales ${ }^{6}$ - e eu tenho grande simpatia pelo Evo - afirmou que “O capitalismo feriu a Mãe Terra!”. E o Žižek fala: "Eu, que sou anticapitalista, quando ouço o Evo Morales dizer isso, tenho vontade de dizer: viva o capitalismo!"”. Por que ele está falando isso? Ele está falando de uma natureza imaculada, de uma natureza pura, entende?

AV: Mas a mãe natureza aludida pelo Evo são milhóes de habitantes no planeta que são prejudicados radicalmente pelo capitalismo. É dessa natureza que Evo fala. 
RG: Claro! Entretanto, há uma captura pequeno-burguesa e capitalista nesse discurso. Mas existe uma mais valia, uma tremenda mais valia sobre uma suposta natureza pura que vira um capital e uma commodity do capitalismo. Isso é muito importante ter claro, porque o discurso da contençáo do consumo é outra face do discurso esquizofrênico do capital. Uma coisa é criticar o consumo pela lógica do biopoder, pela operaçáo de captura do desejo que o consumo é. Outra coisa é criticar o consumo pela operação moralista, onde o consumo é ruim porque ele é desejo.

RG: Mas voltando à agudeza do desejo radicalmente encarnado, me parece que existe uma experiência física limite no limite com a dor na sua performance, Sara?

SP: Sim. Existe um limite.

RG: Que desconstrói qualquer discurso ecologista imaculado da pureza da natureza, porque o grande discurso da natureza não é da natureza como pureza, mas como potência. Como destruição e produçáo.

SP: Certamente.

RG: Tipo isto: pô, cara, não me enche a paciência, vai passar a noite com uma sucuri! Entáo eu acho que a sua performance acaba com qualquer discurso ecologista imaculado, discurso do índio puro.

SP: Sim.

RG: A pergunta já virou quase uma resposta dela mesma: se você achar que eu estou certo, você pode pensar por aí, mas, se eu estiver errado, pensa a partir do meu erro, $\mathrm{OK}$ ?

SP: É, acho que tem tudo a ver, não é, Felipe?

FE: Há, nessa discussão, dois pontos importantes. O primeiro é que não existe nada puro, inclusive o próprio conceito de pureza é natimorto. Náo existe uma capoeira pura. Não existe um candomblé puro. Náo existe uma água pura, pois uma tem mais sódio, outra tem mais cromo, níquel, porque foi contaminada... Bem, é como falar de arte pura, significaria estar pressupondo que existiria uma arte impura. Assim como existiria branco puro, negro puro, capoeirista puro. Pureza seria, portanto, um conceito muleta.

RG: Concordo totalmente.

FE: O segundo ponto é que não está na dor o limite da performance da Sara. Primeiro que não dói. Dói para os outros. Porque a gente testa muita coisa sobre dor. Suspensão dói. Agulha superficialmente... 
SP: OK, como tudo, depende. Enfim, a dor é um negócio muito relativo.

FE: A dor, ela é subjetiva. Para muita gente, dói muito mais depilar. Depilação à cera me dói muito mais do que agulha subcutânea. É um conceito de dor que varia para todos os presentes. Para quem tem um treinamento com dor, aquilo é baba de fazer.

AV: Você disse tudo: o treinamento, a adaptação do corpo...

SP: Acho que existe um treinamento, mas para cada um tem um exercício de acordo com sua subjetividade e seu corpo.

FE: OK. Mas porque, quando se fala em depilação, não se fala de dor? Porque o resultado não é aquilo que se busca...

RG: Tem um ideal asséptico, né?

SP: É... O salto alto e a perna lisa.

FE: É o salto alto, mas não é a dor.

AV: Porque o desejo não é a performance, mas o resultado visual.

FE: Quando se fala em agulha: dor, dor, dor. E isso é um resultado da tragédia. Claro que dói, dói um pouco, mas, se eu ficar puxando pelo por pelo durante uma hora, talvez doa até mais. Tem lugar que vai ser absurdo. Se eu puxar os pelos do meu saco durante meia hora, vai doer muito mais. A dor seria um conceito que variaria muito para cada um. Se tiver sessenta pessoas na sala assistindo à performance, cada um vai ter uma leitura da suposta dor. Uma pessoa que manja do universo da manipulação corporal vai sacar que aquilo não está doendo tanto assim.

AV: Certamente, pois ali a dor não é o central, mas a alusão a ela.... RG: Não está doendo tanto, mas não há dúvida nenhuma de que é uma performance que quebra o ideal asséptico. Isso é a primeira coisa que queria dizer.

FE: Porque ela está no campo do rito de passagem. A dor é um elemento muito forte...

RG: Exatamente. E, por outro lado, voltando à discussão da pureza, a performance da Sara desconstrói e ataca qualquer discurso purista. FE: Por isso que eu falei da imagem do índio... Homem versus natureza.

SP: Do ideal asséptico.

AV: Exatamente. De um homem puro, de uma natureza pura. 
SP: Quando a gente fala em performance, é essa história, né? $\mathrm{O}$ ato performático também corre o risco de ser colonizado e categorizado por um discurso despotencializador...

AV: Como ato emancipatório, é alvo de oxidação regulatória.

FE: Por isso a gente começou essa conversa toda. Na primeira resposta (da Sara), foi isso: "Eu nem sei se a performance está no campo da arte". Porque acho que a potência dela é exatamente não estar no campo da arte, porque o mendigo pode performar... Aqui está a maior tensão que a performance provocaria.

SP: Mas ela não está em nenhum campo limitado e está em todos os campos ao mesmo tempo.

FE: Não que seja a vida pura ou real. Porque existe o momento performático.

AV: A aventura de se pensar a performance implica até em certas decepçóes. Determinadas surpresas, como, por exemplo, o desfronteiramento dos limites que nos dão, ou melhor, definem nossa zona de conforto, que é a plataforma da arte, que nos faz nos encontrarmos. Mas uma plataforma que nós próprios, quando vamos para cima dela, já vamos com a intenção de sabotá-la, né? Não é à toa que fomos parar em um Instituto de Arte. Não é no sentido de uma preservação incondicional daquela instituição quase ou mais que templária. Podemos dizer, por um lado, que é uma expansão desse campo da arte para além das fronteiras institucionais. Então eu não diria que a performance pode náo estar na arte, mas de que arte eu falo? Pode estar até no sentido de uma ampliação. Porque eu pensaria também o seguinte: o que fazemos nessa vida senáo tentar esquecer sua finitude? E, para isso, vale tudo! E aí a gente opera com não lógicos, com alógicos, com contralógicos (o tempo todo). Então tudo é repetitivo via infinitas metáforas. A gente vai produzindo uma metáfora e vamos metaforizando de tal maneira que alcançamos a sensaçáo de uma daquelas impossibilidades que é a coerência. Da mesma forma que nos narcotizamos com a aposta em uma coerência, apostamos em outras coisas impossíveis: Deus, imparcialidade e outras tantas. Falando de coerência, voltando à sua performance - você desejando ou náo - como uma obra posta, uma obra exposta, que transpóe plasticidades que cada um dos presentes criaria em suas cabeças a partir de suas histórias pessoais, dos seus acervos. Então você vira um índio! Um índio contraditório, um índio que é alvo de suas próprias 
setas. Um índio que não é índio, porque ele é um índio animal, índio pássaro, o que faz ser mais índio ainda, porque os índios são animais, plantas, tudo ao mesmo tempo. Entáo é como se fosse, dentro daquela meticulosidade toda, daquela ourivesaria performática, um ato poético, sem trair a sua espontaneidade, mas perfeitamente dentro dos padróes da linguagem, sobretudo da sintonia de um mundo da arte, de um mundo de um refinamento muito grande, porque sua obra, em muitos aspectos, é quase renascentista (eu já falei para você isso, né?) no que de permanente e atemporal pode ter esse termo. Você traz também dentro de você a coisicidade do ente, você traz a coisicidade da ocidentalidade, algo que remete a uma sorte de capital ancestral, todo o peso da potência da sofisticaçáo da ocidentalidade. Então é a partir dessa contradição (a gente abriu mão da coerência) que trataríamos da contradiçáo como elemento poético que náo se implode, mas sim....

SP: Se explode.

AV: Se explode?

SP: É, se amplia.

AV: Se explode, se amplia, se constitui, se afirma, né?! Daí que eu peço que você retome a palavra.

SP: Mas essa coisa de retomar uma ancestralidade, mas que não é uma ancestralidade de raiz ou tradicional?

AV: Não, não, de forma nenhuma. Algo como o retorno do tempo e do recalcado...

SP: Enfim, quando eu olhei aquele texto do Derrida, O Animal que logo eu Sou, eu dei uma pirada, eu dei uma pirada legal, porque comecei a pensar no trabalho que a gente fez na defesa, né? Enfim, tudo que aquela experiência.... O processo que foi até chegar a ela, porque foi um processo longo. Realmente foi um processo de dois anos de construçáo de um trabalho, que eu acho que ele veio de desejos principalmente. De um desejo de fazer alguma coisa, náo que abolisse o campo formal, porque eu me propus a me colocar num lugar de formalidade, inclusive num lugar de formalidade da palavra, porque, no mestrado, a gente tem que escrever (não tem essa opção de eu acho que vou escrever uma coisinha). Não. Tem que escrever. E de como essa construçáo da palavra foi junto com a necessária construção corporal, de uma dramaturgia mesmo, de 
uma roteirização de um processo. Porque o que a gente estava pensando - quando eu falo a gente, falo de mim, falo do Felipe, falo de todo mundo que está dentro de mim também. Pensávamos em um processo que continha a aceitação de sua formalização, que náo se oporia como efetivamente não se opôs à construção poética, incluída toda a dor que lhe foi intrínseca. Quando eu estava suspendida, por exemplo, na última experiência desse tipo, me deu um branco, um negócio, tá ligado? Mas eu não sei dizer o que era esse negócio. Uma sensação forte, indizível. E como é que eu vou escrever sobre isso? E era um caminho meio da bosta mesmo, de você comer e digerir, e aquilo virar um bolo fecal e passar lá em todas as suas entranhas e não sei o quê e passar e passar até sair pelo seu cu e pá, eu fiz aquela merda, né? E foi exatamente isso que eu fiz, eu fiz uma merda, né? Eu comi um monte de coisas, e não só durante dois anos, mas durante a minha vida inteira. E eu fui comendo um monte de coisa e, de repente, eu precisava cagar um negócio que falasse, que desse conta dessa corporeidade, dessa fisicalidade que eu construí com monte de gente também, né? Porque nunca é um processo solitário. Envolve um monte de gente que contribuiu para o processo: cada um de uma maneira. Passamos um período morando na Usina e frequentávamos a floresta da Tijuca, vendo aqueles gramados que são terreiros de despacho praticamente. E tudo aquilo, para mim, era muito lindo, e eu comecei a pirar nos urubus. Gente, o urubu é um pássaro majestoso e tem aquele leque de asa, branca e preta. E um pescoço pelado e uma cabeça esguia que me encantou e interessou muito. Comecei a ler sobre mitologia indígena, na qual é o urubu rei que dá a sabedoria do fogo... Que é a sabedoria que faz a gente ligar essa câmera. E é quase um Mefisto e é muito parecido com o mito de Prometeu também, sobre o qual a gente conversava no começo do mestrado. E das coisas de Sáo Paulo também, onde fizemos parte de um grupo de astrologia de lua cheia, quando discutíamos a mitologia do Hércules, que é justamente a mitologia de colonizar o instinto, tornar o corpo dócil. Aí eu comecei a entrar numa piração, pois também queria experimentar umas coisas com as agulhas. Aí a gente conheceu o Ronato, que foi um divisor de águas, porque ele é um cara que mexe com o sangue (e muito sangue). Enfim, ele ensinou umas coisas para gente e eu comecei a fazer experimentos com o sangue (eu e Felipe) e aí misturei com a ideia do urubu e a mitologia indígena e a palavra que não tangencia. Então decidimos 
apelar para o corpóreo total, para a penetraçáo intensa do corpo, colocar muitas agulhas que seriam penas também, que é quase uma agulha orgânica, quase é contaminada.

FE: Inevitavelmente uma flecha.

SP: Inevitavelmente uma flecha e acho que funde mesmo os sentidos do aspecto mais colonizador, ou talvez mais formalizador, que estaria em um roteiro, uma dramaturgia, uma ação, uma organização plástica. Como é que se construiria essa plasticidade? De quase uma pintura... Como um quadro vivo! Do qual cada close é um flash, a cada flash um close, cada movimento uma foto, uma imagem que também é, embora não somente, nem centralmente, pictórica. Um quadro. E essa dinâmica vai se condensando de um jeito que escapa de uma lógica expressiva específica, pois emerge como rede de acontecimentos expressivos, poéticos, plásticos, artísticos... Eu já não sei mais se a construção que realizei decorreu da intenção de fazer uma performance ou se eu fiz a performance porque eu queria resgatar uma coisa da minha vida... Certo é que eu precisava ritualizar aquilo. Então o limite entre o ritual e a performances se revela muito tênue. AV: Que também não é nenhum problema absolutamente. Ou é um novo desafio lidar com a ambiguidade dos limites da obra contemporânea que náo consegue, ou náo deve, represá-la em um contexto estável e preciso. Contudo, há um eloquente e oportuno devir nessa ambiguidade, na qual as categorias se diluem e não se pode saber se se está fazendo um ato poético ou se está em busca de outra coisa. Ou se essas duas dimensóes são a mesma coisa.

SP: É. E eu acho que isso é que é interessante na performatividade, na performance e tal. Porque realmente há a mistura dos campos. $\mathrm{O}$ que propicia a ampliação do que se pode ser. $\mathrm{O}$ que pode ser, o que pode ser performance. Uma discussão que, enfim, dura meses. AV: Esse deslimite, esse desfronteiramento do ato performativo já está implícito na tua aventura, na tua escolha, no teu ato poético e intelectual.

SP: Total. E que eu acho que vai ao encontro daquilo que a gente sempre discute, de como se dá o aparato educativo, educacional ou como a gente quiser nomear, mas de empoderamento de um conhecimento que foge às regras da tradição do que é e do que não é epistemologicamente legítimo ou aceitável. 
AV: E obviamente que tudo implica um risco. E é uma bobagem ficar fazendo avaliação de custo benefício, considerando apenas o risco, que seria no plano da superficialidade.

SP: É um risco bobo, né? Eu acho que os tempos, eles são de guerrilha mesmo, e a gente precisa ir um pouco além (não que a gente precisa, porque todo mundo precisa), mas assim, há um desejo de explosão coletivo, me parece.

AV: Ir ao encontro do corpo do outro. Eu me lembro de uma frase, que eu sempre repito, do meu parceiro de pesquisa, o Aristóteles Berino, já que você falou em educação, que afirma que "[...] é preciso que o corpo do professor seja colonizado pelos seus alunos". Penso em um corpo sensibilizado pela ocupaçáo do outro...

SP: Isso é lindo.

$\mathrm{AV}$ : Isso, acho que não tem outra palavra. Acho que não tem outro termo. Entáo esse ato performativo dentro dos espaços propostos como espaços pedagógicos da educaçáo, do ensino - e a gente sabe que se expandem - nunca pertencem a algum proprietário único da escola. E também a inclusão que você cita: o meu corpo se expande de tal maneira que engloba, não engole, não destrói, mas engloba, partilha do corpo do outro. E é partilhado por esse outro.

SP: É, total. Pelo menos para mim, as experiências pedagógicas e de ensino sempre foram muito viscerais. Sempre percebi que o espaço que a gente tem na escola ou na instituiçáo acadêmica, que seja universidade, no museu, enfim, tem, no aspecto positivo, o poder de ampliar as nossas açóes e de contribuir para um projeto assim ou assado que pode servir a algo maior que a mera participaçáo no circuito da arte. Pois as instituiçóes oferecem um espaço com uma infraestrutura interessante que facilita fazer algumas coisas. Por exemplo, no pré-primário, fazer xixi na aula é uma coisa; no grupo de estudos, na garrafa bonita, é outra.

SP: Às vezes, esses espaços de doação e de acolhimento, enfim, de empoderamento do sujeito, eles dão ferramentas mesmo, dão oportunidade. Acho que oportunidade não é uma palavra ruim, não. Necessário para a gente poder fazer algumas coisas, até para se contradizer. AV: Certamente. Somos, em muitos momentos, autores dos espaços. O problema é tomar consciência de que nada vai acontecer diferente daquilo que fizermos coletivamente. 
SP: E é por isso que depende de uma construção, que realmente é coletiva. E quando você fala essa frase do Aristóteles Berino, da colonizaçáo do corpo do professor, eu acho que tem um cabimento até terrível, saca? Que mostra um diagnóstico que é apavorante às vezes. De quanto (e eu me coloco nesse lugar também) por que eu estou aprendendo também. De como a gente se coloca no campo do professor como aquele que vai falar uma verdade ou que vai colocar uma questáo que vai ser de total importância para o resto de nossas vidas. E quando, na verdade, a coisa vai se construindo, ela vai no gerúndio mesmo, entendeu? Vai se desenrolando na troca cotidiana. Então, por exemplo, se eu não tivesse conhecido você (Aldo), ou se eu não conhecesse o Felipe, eu não ia fazer a performance que eu fiz e que a gente está falando agora! Ia ser uma outra coisa, ia estar fazendo uma outra parada. Talvez a gente até estivesse fazendo performance, mas certamente seria diferente. Entáo é isso que me encanta, porque tanto na educação quanto na performance, você depende do encontro. Por mais que você faça um roteiro ou tenha um postulado apriorístico, você depende daquele encontro para a construção daquele saber específico. É daquele coletivo, é daquele encontro.

AV: E você diria que o grau de escamoteamento do corpo seria a régua dessa relação de sucesso? Eu vejo esse ato de exclusão, inclusão, agregação, e essa colonização, como pornoeróticos. Mas isso só pode acontecer quando o corpo não é escamoteado, não é fraudado.

SP: É um exercício de vida mesmo.

RG: E a relaçáo entre corpo e caos?

SP: É o corpo, é o caos. O corpo é o lugar do caos, eterno e profundo.

FE: Não que seja isso na performance necessariamente.

SP: Não, mas é que, na hora da performance, a gente organiza o caos.

RG: Eu quero chegar aí. O que eu queria colocar é que há dois limites possíveis: há um limite do corpo como esse corpo gaiola, esse corpo que nos aprisiona, que tem a ver com Nietzsche na Genealogia da Moral, que fala que o homem é "[...] esse animal que se feriu nas barras da própria jaula" que teria criado para si. E há uma outra situaçáo limite que está no limiar da potência, da criação, da invenção, da expansão. Você vai no limite para expandir, mas, ao mesmo tempo, você tem que sustentar uma certa integridade.

SP: (balança a cabeça afirmativamente) 
RG: Em vez de fazer um jogo de xadrez com a morte, como no filme do Bergman ${ }^{10}$, você faz um jogo de xadrez com o caos.

SP: É.

RG: O que talvez seja um jogo de xadrez com a morte, mas a morte no sentido menos cristão.

SP: A morte no sentido mais...

RG: Isso: a morte como uma vida táo imensa que atropela nossa miséria de verme. Me lembro, assim de memória, que Nietzsche disse algo como "A humanidade é uma doença de pele do planeta". É como se nós fôssemos uma micose ou uma psoríase da Terra.

FE: Quando está em caos absoluto.

SP: E eu tenho psoríase. Quando estou em caos absoluto.

RG: Eu estava relendo o conceito de força plástica em Nietzsche ${ }^{11} \mathrm{e}$ descobri que entendia ele de forma limitada, uma vez que eu sempre o identifiquei imediatamente com a vontade de potência. Ele tem uma relação importante com vontade de potência, é verdade, mas força plástica é exatamente essa força que faz com que a gente, diante de toda pressáo do caos, consiga manter uma integridade física, mas não como uma resistência negativa, mas como algo que consegue captar toda essa potência do caos para que o nosso corpo vire produtivo, à medida que consiga fazer convergir, deixar passar e...

A1: E se transformar.

RG: E se transformar. Aí sim vem a vontade de potência. Aí sim ela opera.

SP: Eu acho que ela opera em todos os cantos, saca? É porque o caos eu acho que é essa energia do parto mesmo. Nossa Senhora, quando a gente vai nascer fica ali, pá, cozinhando, cozinhando, cozinhando, cozinhando. Até tem uma hora que o negócio que tem isso aqui, ele dilata dez centímetros e vira isso aqui. E aí a bacia abre e tudo abre e... Pari aquele negócio. Imagina o cabeção, cara! Imagina o cabeção! É difícil! É difícil mesmo quando é o parto de cesária: você vai lá e pá, corta, tira.

SP: É uma mágica. Parto normal, caralho!

RG: E só para concluir a pergunta. Eu acho que, para quem trabalha com a performance do corpo como vocês, como foi lidar com a medicina, com a internaçáo, com procedimentos microcirúrgicos, cirúrgicos e tudo isso, que vocês passaram há pouco? 
SP: A gente lidou com o limiar da morte total.

$\mathrm{AV}$ : E a cura também?

SP: Cura e o processo de cura e com o processo de aceitação de passagem. Porque é o seguinte: para mim, até o segundo dia, Felipe estava com a possibilidade morte iminente.

FE: E, no segundo dia, entrou uma passeata na sala de emergência onde eu estava.

RG: Entrou gás lacrimogêneo e tudo.

SP: Então a gente teve um encontro de medicina e tudo. Foi muita treta. Mas o corpo quer muita coisa. O corpo sem órgãos, que está em todo mundo: é o negócio mais ontológico que pode existir. E aí eu acho que tem essa força mesmo de potência, de expansão do corpo, quando o corpo explode.

RG: Por isso que estávamos falando de um lugar limite do corpo que náo é o lugar limite que aprisiona o corpo, mas é o lugar limite da expansáo do corpo, em que ele negocia com o caos, mas, ao mesmo tempo, tem que, de alguma forma, manter a integridade para continuar potente... Não é a integridade da moral, mas é a integridade do corpo criador.

SP: E eu acho que o que a gente faz não é só um limite, mas é uma das possibilidades de limite, porque limites tem muitos. Você tem o limite do cara que fuma crack, por exemplo. Já conheci uma galera que fumava crack (imitando): Cara, eu gosto muito de fumar crack, eu fico doidão, mas ó, eu tenho dinheiro aqui, se eu quiser comer, eu como, se eu quiser alugar um quarto, eu alugo, mas eu quero ficar na rua, morando na rua, fumando crack. Eu acho isso totalmente legítimo. Porque é o que faz o cara ter prazer. A vida é um negócio cruel, a vida é um negócio que te deixa doido. O limiar para você ter um surto psicótico, começar a querer quebrar tudo, querer cortar as pessoas e não sei o quê é um limite muito tênue: falta muito pouquinho para a gente chegar nesse limite. Talvez se a gente morasse no mato, a gente náo teria vontade de cortar os amiguinhos, a gente teria vontade de cortar os bichos, a gente ia caçar, pescar, pegar uma planta, colher umas tartarugas, fazer uma sopa. Mas a gente quer ficar se matando mesmo porque, enfim, a gente tem uma carência de sei lá o quê, de dar uma explodida mesmo, fazer as bacantes, estraçalhar o corpo de quem quer que seja: estraçalhar o bode. 
RG: A partir daí, eu queria avançar um pouco para a relação entre desejo e violência. Eu acho que existe, no seu trabalho, uma violência legítima, entende? Mas, ao mesmo tempo, nós, sem dúvida, somos parceiros, com todas as singularidades que existem aqui, na resistência aos horrores da violência do poder.

SP: É porque eu acho que a gente fala de uma violência da instituiçáo e de uma violência do animal. Eu acho que, quando a gente faz performance, a gente fala da violência do animal, é a violência do instinto de sobrevivência, entendeu? Eu não preciso sangrar porque eu quero mostrar para todo mundo... Olha, eu sou forte pra caralho, eu me fodo toda, eu não sei o quê... Eu não quero mostrar que eu me fodo toda, eu quero me foder toda porque eu preciso, eu preciso sangrar daquele jeito, entendeu? Eu preciso que sangre muito, eu preciso que doa, eu preciso que sue, eu preciso que seja um negócio assim, me leva para um estado em que eu vou quase morrer, eu vou quase ter um troço, saca? É um troço.

$\mathrm{AV}$ : É uma ascese?

SP: É uma ascese. Mas não é só uma ascese porque eu estou procurando por uma transcendência. Náo tem nada de transcendência, mas tem a ver com um estado de experiência que ele mergulha para um estado de sobrevivência mesmo. É a experiência de estar vivo. Eu só sangro porque eu estou viva. Se eu estivesse morta, não sangrava. RG: Mas é mais que sobrevivência, é expansão da vida.

SP: É expansão da vida, é transbordamento da vida. Que é isso mesmo, a gente fica enchendo o copo, e tem uma hora que ele começa a cair para o lado.

AV: Você está falando de limites e deslimites, e a metáfora do copo que o Felipe aponta me parece bastante pertinente. Talvez seja o que a gente chama de campo da arte ou campo poético expandindo as possibilidades de combinaçóes da vida, de realizaçóes da vida, de teatro, de gestos, de tudo para além dos limites pautados por uma determinada norma, que é instrumento produtor, produzido ou decorrente de uma coerção generalizada. Daí vem a força pedagógica do ato performativo, a força pedagógica do ato poético. Agora aquilo que chamamos de dor e, discorde se eu tiver equivocado, que a gente rapidamente chamaria de sofrimento - e, num segundo momento, deascese - seria apenas algo diferente do autorizado. 
SP: É, e eu acho que é lindo assim: é tão bom que a gente é diferente, saca? Ai, que rico, é rico mesmo.

RG: A gente falou um pouco da negociação com o caos, desse limite com o caos. Aí eu vou falar da negociação com o poder e com a violência, que também tem um jogo de xadrez aí, o tempo todo. Eu vejo extremos, claro. A gente já falou dos índios aqui, mas nós vivemos numa polaridade que é violenta, e que eu acho que a superação, uma das mais interessantes que eu vi, de ser feita dessa polarização foi feita pelo Zé Celso ${ }^{12}$ em determinada cena dos Sertóes. De um lado, um discurso de que há, no Brasil, uma grande comunhão sexual entre dominados e dominadores, de que havia prazer nas escravas em servir os seus senhores.

SP: Sim, essa porra toda.

RG: Do outro lado, um discurso, vamos dizer, anticolonialista, num certo sentido marxista clássico, que denuncia o estupro no lugar desse discurso do prazer, o que é uma virtude desse discurso fazer a denúncia do estupro branco, mas, ao mesmo tempo, tem o problema de banir o desejo e a sexualidade. Eu digo isso porque tem uma cena dos Sertóes, do Zé Celso, que parece que ele conseguiu pegar os dois discursos e encontrar a potência dos dois.

SP: Ai, que lindo.

RG: Ele descreveu o estupro, mas ele conseguiu descrever que o dominado tem tesão no dominador, no poder... Tá entendendo? Então quer dizer que há uma negociação de desejo.

SP: A gente tá falando do sadomasoquismo (risos).

RG: Não, mas em furtar poder. Eu tô falando também da sensualidade do poder.

SP: É o sadomasô... O escravo tem um desejo intenso no seu senhor. Ele contrata o senhor, o escravo é quem contrata (risos). Ah, sei lá, eu tô viajando também (risos).

AV: Mas esse vocabulário é ambíguo. De uma ambiguidade enorme. Acho difícil traduzir as leis dos desejos. Ou melhor, traduzir as leis do corpo a partir de uma matriz política específica que não é nascida e realizada nesse próprio corpo. A gente vai pegar uma política conceitual, teórica regulatória e tentar acoxambrar num corpo que é contraditório. Num corpo que seduz o senhor e que transforma o senhor em escravo no ato performático da transa. 
RG: Mas isso determina a vitória política do Gilberto Freire. Veja bem, isso não é defesa de Gilberto Freire ${ }^{13}$, mas é a compreensão do grau de sofisticação que o Poder chega num lugar como o Brasil.

SP: Ah, mas o poder sempre foi de uma complexidade insofismável! $\mathrm{Na}$ África, tinha impérios! A história dos orixás é a história de reis e rainhas dos impérios africanos.

AV: E os africanos praticavam o escravagismo, certo?

SP: Sim!

RG: Os poucos intelectuais europeus que leem Gilberto Freire ficam perplexos, mesmo que constatando a violência perversa daquilo tudo. Eles olham para aquilo e dizem, Nossa! Como vocês produziram isso? O que levou isso a ser produzido? Nós náo somos gilberto-freirianos, e isso está muito claro, mas como é que a gente fecha nossa lente nos aspectos desejantes, que são de fato os aspectos políticos, da relação colonizado-colonizador, de maneira libertária? Porque também não somos beatas marxistas, entendeu? A gente náo vai condenar ninguém à cruz porque achou que a piroca ou a buceta do colonizador eram interessantes.

SP: É porque a gente é muito hippie.

AV: Faz de conta que a gente volta ao corpo e diz assim, Não, o corpo de fato transborda a possibilidade hermenêutica. Então eu não vou explicar aquilo que movimenta um corpo. Náo vou poder reduzi-lo ao esquema que é aplicável dentro de outro campo conceitual. Nem sei se, na verdade, ali quando a escrava tá comendo o senhorzinho, se de fato ela tá comendo ou não, se de fato tá acontecendo uma inversão ou náo, ou se isso interessa a ambos. Haveria alguma coisa de tão selvagem na sexualidade, como sinônimo de estranho e diferente do mundo da cidade da palavra, que nos jogaria sempre numa sinuca de bico. A gente sempre vai falar muito menos, vai significar muito menos por meio da palavra que por meio do ato erótico, do que o ato sensorial produz e realiza. Voltando, entáo, ao ato de violência policialesca, é inegável o prazer que o policial tem em atirar na garotada. RG: É verdade.

SP: Nossa, é espetacular mesmo.

AV: Eu me lembro que eu tentava encarar os caras, e o olhar deles foge ao teu olhar. Eles sabem que eles náo podem te encarar, porque eles não podem perder aquela concentração magistral, são artistas em ato. Eles estão numa concentração absurda. 
RG: É como no filme do Kubrick, Nascido para Matar. Aquele processo de condicionamento que o Kubrick desconstrói e que o Padilha, ao contrário, faz apologia na Tropa de Elite.

$\mathrm{AV}$ : Na linha de fogo do palácio Guanabara, eu pensei como aquilo era espetacular! Porque os tambores, que não eram tambores, na verdade, eram as bombas... E como eles marchavam? Era apoteótico, estético!

SP: Eles se acham, eles se acham o total. Mas olha, o black bloc vai arrasar!

AV: Lógico que a gente não vai defender a posição política, a repressão violenta, quando aludimos à performance dos policiais. Não seria ecológico.

SP: A gente não quer, não é o nosso desejo.

F: Tortura nunca mais.

RG: Tem uma outra história do Zé Celso, e eu estou muito zecelsiano hoje...

SP: Ah, acho ótimo.

RG: Pois é: ele pegou aqueles meninos que ficavam perto do Teatro Oficina em São Paulo, que é uma região ali que tem uns bandos de rua e tal, uma regiâo que é, ou foi em certo momento, bastante degradada, no sentido padrão do termo degradado, e ele começou a dar aula de teatro pra uma garotada. E ele tinha o hábito de chegar ao teatro antes da hora de começar a aula, e os meninos já estavam lá esperando. Então ele ficava meio na espreita escutando os meninos contarem as histórias dos assaltos que eles faziam. Os meninos contavam cada assalto, cada bolsa que levavam, sei lá mais o quê, com uma tremenda excitaçáo... Aí o outro já queria tomar a palavra, e aquilo numa excitaçáo impressionante, e Zé Celso pensou assim: Como é que eu vou ensinar teatro pra essa molecada? Eu só tenho uma chance: se eu conseguir fazer o teatro ser mais excitante para eles do que isso. Mas quem é que tem a coragem de colocar o problema da violência nesses termos além do Zé Celso?

(Ouve-se um barulho de sirene.)

SP: Acabou de passar um carro da polícia, não passou?

Todos: Sim.

SP: Ele vai pegar alguém agora, tá ligado? E, com certeza ou muito provavelmente, esse alguém é um menininho pretinho, que tá ali 
na Lapa, batendo a carteira de alguém, ou pegando uma bolsa, ou uma briga, uma parada assim. E eu fico pensando que o policial, às vezes, ele tem um prazer muito... E isso é foda, porque eu já tive vizinhos policiais no bairro em que eu morava. A coisa da polícia é um negócio muito complicado porque a gente tem uma polícia que não é só uma polícia civil. A gente tem uma polícia civil e militar. São duas polícias diferentes. E polícia do exército...

AV: E tem as milícias também.

SP: É, junta uma porrada de polícia! O problema é que eles têm aquelas armas, que afirmam não ser letais, o que é uma puta duma mentira, porque uma pessoa com asma crônica, no meio de uma manifestação, com bomba de gás lacrimogêneo, como já teve na UERJ, eu tava lá, e eu senti o gás arder na pele, fode com a pessoa! Não tem arma não letal. E arma, bala de borracha, fura, entendeu? Ela fura olho.

AV: Agora o problema é que esses caras são tão parecidos com a gente... Isso que é a grande merda.

SP: Eles são parecidos, mas eles não estão lutando pela sobrevivência deles, eles estáo lutando pela sobrevivência do Estado, que é uma coisa invisível. 


\section{Notas}

${ }^{1}$ Martin Heidegger (1889-1976) foi um filósofo alemão, um dos mais influentes do século XX, que se tornou conhecido por propor a superação da metafísica (re)colocando a questão sobre $o$ sentido do Ser num grau de radicalidade do qual teriam se aproximado filósofos pré-socráticos como Parmênides e Heráclito, e que teria sido abandonado a partir de Platáo e Aristóteles. Ex-aluno do fenomenologista Edmund Husserl (1859-1938), Heidegger teria ido além de seu mestre, sendo considerado, nos manuais de Filosofia, um dos fundadores do existencialismo.

${ }^{2}$ Valesca dos Santos, ex-vocalista do grupo Gaiola das Popozudas, que se constituiu, há alguns anos, num dos maiores expoentes do funk feminino (ou feminista, para alguns), juntamente com a cantora Tati Quebra-Barraco. O grupo, comandado por Valesca e suas dançarinas, fez duas turnês internacionais em 2011 e lotou os shows nos Estados Unidos (Washington, Miami, New Jersey e Boston). Valesca tem hoje uma carreira solo e estourou um dos clipes de maior sucesso na internet nos últimos anos: Beijinho no Ombro.

${ }^{3}$ Depoimento de Darcy Ribeiro em O Povo Brasileiro (1995), documentário em dois episódios feito a partir do livro do antropólogo Darcy Ribeiro (1922-1997) com o mesmo título, dirigido por Isa Grinspum Ferraz e produzido pela Fundação Darcy Ribeiro e pela produtora Texto e Imagem.

${ }^{4}$ Nome dado à ocupação do antigo prédio do Museu do Índio, ao lado do estádio de futebol do Maracanã, no Rio de Janeiro, feito por indígenas de diversas etnias e ativistas políticos em geral. Essa ocupação desencadeou uma longa luta política pela instalação no local de uma espécie de escola indígena, com apoio de vários setores da sociedade, mas com a oposição firme, muitas vezes recorrendo à repressão e à violência policial por parte das autoridades do Estado.

${ }^{5}$ Slavoj Žižek (1949-presente), filósofo esloveno, é uma das principais estrelas do pensamento marxista contemporâneo, além de ser um importante estudioso de Hegel e de Lacan.

${ }^{6}$ Evo Morales, atual presidente boliviano, foi o primeiro presidente de origem indígena do país, vindo da etnia uru-aimará. Antes de tornar-se presidente, em 2005, Morales se destacou como ativista de movimentos sociais indígenas e campesinos, liderando grandes mobilizaçôes políticas.

${ }^{7}$ Referência feita em conferência realizada no Cinema Odeon, no Rio de Janeiro (25/05/2011), pelo filósofo Slavoj Žižek ao presidente boliviano Evo Morales e seu culto a Pachamama (Mãe Terra) como um discurso político. Nesta mesma palestra, logo em seguida, Zizek reiterou que apóia politicamente o Presidente Morales, apesar desta crítica.

${ }^{8}$ Educação e Imagens: instituiçôes escolares, midias e contemporaneidade (Berino; Soares, 2011, s.p.).

${ }^{9}$ Genealogia da Moral (Nietzsche, 2004, p. 73).

${ }^{10}$ Referência ao filme O Sétimo Selo (1956), do cineasta sueco Ingmar Bergman (1918-2007), em que o protagonista disputa uma partida de xadrez com a morte.

${ }^{11}$ Friedrich Nietzsche (1844-1900), filósofo alemão, foi o autor de uma imensa ruptura na histórica da Filosofia, rompendo com os paradigmas do iluminismo e com a teleologia histórica hegeliana. Crítico e desconstrutor da moral judaico-cristáo ocidental e da filosofia moral iniciada por Sócrates e Platão, que opóe o modo de pensar trágico. Nietzsche busca mostrar como a noção científica de verdade e a crença do Ocidente na Razão têm as suas origens nessa moral. Nietzsche é o criador do importante conceito de vontade de potência, afirmando um vitalismo e um perspectivismo, a vida como imanência, como o que se afirma em si mesmo e que deve se libertar da amarra de toda e qualquer transcendência, ou seja, de todo e qualquer princípio que 


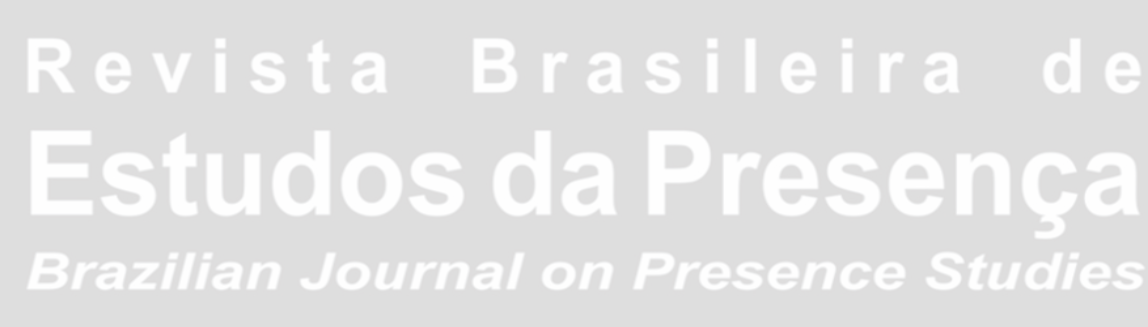

para além da vida pretende julgá-la. Conceitos como os de eterno retorno e os de super-homem (o homem para além do homem) também são fundamentais na Filosofia de Nietzsche.

${ }^{12}$ José Celso Martinez Corrêa (1937-presente), um dos mais importantes diretores de teatro, encenadores e dramaturgos brasileiros, uma espécie de pensador do e através do teatro, experimentador radical, antropofágico, dirige o grupo de Teatro Oficina em São Paulo desde os anos 1960. Diretor, entre inúmeras peças, da primeira montagem da peça de Oswald de Andrade O Rei da Vela (1967), bem como montagens mais recentes como a sua versão da tragédia grega As Bacantes, de Eurípedes, e uma enorme e ousada adaptação para o teatro do romance Os Sertóes, de Euclides da Cunha.

${ }^{13}$ Gilberto Freire (1900-1987), escritor e antropólogo brasileiro, foi autor de clássicos como Casa Grande e Senzala e Sobrados e Mocambos. Freire foi o principal responsável pela criação do mito da democracia racial, que veio a ser, mais tarde, duramente criticado por escamotear, e até mesmo manter e aprofundar, o racismo no Brasil. Sua obra, no entanto, é muito mais complexa e vasta para ser reduzida apenas a essa crítica, ainda que ela seja pertinente, sobretudo no que se refere à apropriação conservadora que foi feita de seu pensamento.

Aldo Victorio Filho é professor adjunto e vice-diretor do Instituto de Artes da Universidade do Estado do Rio de Janeiro (UERJ), coordenador do curso de Licenciatura em Artes Visuais e docente dos Programas de Pós-graduação em Artes e em Educação da mesma universidade. Mestre e doutor em Educação, ele pesquisa Estéticas Periferizadas e Epistemes da Rebeldia.

E-mail: avictorio@gmail.com

Rodrigo Guéron é professor adjunto do Instituto de Artes da UERJ, coordenador adjunto do Programa de Pós-graduaçáo do Instituto, mestre e doutor em Filosofia. Autor do livro Da Imagem ao Clichê, do Clichê à Imagem: Deleuze, cinema e pensamento (2011), é também cineasta, roteirista e autor dos filmes curtas-metragens 750 - Cidade de Deus, Clandestinidade e Eu Estou Bem Cada Vez Melhor.

E-mail: rgueron@uol.com.br

Filipe Espindola é artista plástico e performer. Formado em Artes Plásticas pela Universidade Estadual de Campinas (Unicamp), produz colagens desde 1994 e fundou, com mais três artistas, o Grupo Neotato em 1997, participando de exposiçóes em Campinas, Sáo Paulo, Vitória e Salvador. Reside atualmente no Rio de Janeiro, onde coordena o ateliê Casa 24.

E-mail: sara.panamby@gmail.com

Sara Panamby é artista performer e bacharel em Performance pelo curso de Comunicação e Artes do Corpo, da Pontifícia Universidade Católica de São Paulo (PUC-SP). Mestre e doutoranda em Arte pelo Programa de Pós-graduação em Artes da UERJ, é professora na mesma instituição e coordena, juntamente com Filipe Espindola, o ateliê Casa 24. Tem realizado bem-sucedidas apresentaçóes de seu trabalho no Brasil e no México.

E-mail: sara.panamby@gmail.com

Recebido em 22 de maio de 2014 Aceito em 01 de julho de 2014 